\title{
Investigating brand personality of state-owned and private airlines: Maham Versus Iran Air
}

\author{
Mahdi Karoubi and Seyed Ahmad Taghavian Noghan*
}

Department of Management and Accounting, Allameh Tabatabaei University, Tehran, Iran

\begin{tabular}{|c|c|}
\hline CHRON I C L E & ABSTRACT \\
\hline $\begin{array}{l}\text { Article history: } \\
\text { Received December 28, } 2013 \\
\text { Received in revised format April } \\
152014 \\
\text { Accepted April } 182014 \\
\text { Available online } \\
\text { April 30 2014 } \\
\text { Keywords: } \\
\text { Brand } \\
\text { Brand Personality } \\
\text { Airlines } \\
\text { Aaker's Model }\end{array}$ & $\begin{array}{l}\text { Today, companies need to create exclusion not in the market but in their own capabilities and } \\
\text { features in order to gain distinction. The creation and maintenance of distinction through } \\
\text { functional features is nearly impossible anymore. Thus, apart from the functional features, } \\
\text { companies need to consider their intangible properties, among which brand is one of the most } \\
\text { important ones. One of components researchers have detected for brand is personality, which } \\
\text { can enhance the preference and loyalty of the customers and influence their decision process. In } \\
\text { the service section, due to its specific features, the impacts of brand personality are more } \\
\text { important and more complicated and airline companies, as service industries, which provide } \\
\text { one of the most intangible products, are no exception. In the current study, using Aaker's Five- } \\
\text { Dimension Model for brand personality, brand personality of a state-owned airline company } \\
\text { (Iran Air) and a private one (Mahan) are compared from the perspective of technical directors } \\
\text { of travel agencies. The population includes } 233 \text { technical directors whose views regarding } \\
\text { brand personality of airline companies are studied following the distribution of questionnaires. } \\
\text { The results of the data analysis indicate Mahan Airline is superior to Iran Air in all the five } \\
\text { dimensions. }\end{array}$ \\
\hline
\end{tabular}

\section{Introduction}

In today's marketing, branding is not limited to assigning a name or trademark to a product or a particular firm and managers, by creating brands, are not solely aiming at introducing their product with that name. Company managers and owners are constantly trying to differentiate their brands to build competitive advantage. In the past, these attempts were concentrated on products, services, and their functional advantages. However, more intensified competition because of gradual appearance of new competitors made differentiation through brands' functional features less effective and symbolic meanings gradually turned into a basis for the positioning and differentiation of brands. Consumers 
often express brands in terms of human characteristics and marketers. They also try to build and to reinforce such images in consumers' mind with the help of marketing techniques such as advertising.

The use of human characteristics for brands drew the attention of many researchers of this field to a new construct called brand personality. Aaker (1997) defined brand personality as a series of human features or characteristics that consumers attribute to a brand. A proper brand personality can lead to an increase in preference and consumption (Sirgy, 1982), emotional bonds with brand (Biel, 1993), and trust and loyalty (Fournier, 1994). Brand, also, has to have a personality, which suits the personality of its target market because consumers prefer a brand, which fits to their personality and introduces them well (Sirgy, 1982). Another important thing to add is associated with consistency, which is important in creating a successful brand personality. Branding is a strategic endeavor and requires a comprehensive and long-term outlook. Understanding current situation is the first step to embark on this long-term path.

This study compares the status of brand personality in Mahan and Iran Air, which are two Iranian airlines. These two airlines are different in that Iran Air is a state-owned and Mahan a private airline. Their comparison, thus, reveals whether the variable is associated with state-owned as well as private one influences the status of brand personality in these two companies or not.

\section{Research Problem}

In the tough competition of commerce today when enterprises are constantly creating innovation, differentiation and its maintenance are difficult tasks. Influencing customer's decisions, moreover, requires considering many factors, which customer's mental image of brand is noteworthy. As an invisible asset, brands help organizations differentiate themselves from their competitors. They also play significant role in the growth and profitability of organizations in the long run. Furthermore, now it is possible to protect brand and trademark based on legal measures. Brands play important roles from differentiating product or service to making relationships with customers, leading to market awareness and loyalty, and increasing on the market share. Customers today expect products to have brands and logos and even when a particular product is in a better position, they normally prefer to purchase the one, which is their favorite brand. There reason for this seemingly irrational decision can be a series of human characteristics detected in a brand and this new construct is called brand personality. Brand personality is an efficient tool in marketing because making a context for attracting any individual to a brand facilitates maker penetration and creates loyalty. If people detect features in the product, which matter to them, they associate themselves more with it and, as a result, they may choose that particular product (Asperin, 2007). Therefore, the more the affinities between individuals' personality features and a brand, the higher is the chance of choosing that product by them. This along with the fact that effective factors in today's commerce pay more attention to customers obliges every organization to use brand personality in order to have a deeper understanding of its consumers and investigate it in its customers' minds.

In recent decades, tourism industry has experienced an ever-increasing growth and governments as well as private sector has made considerable investments in this area. In the same vein, airline industry has had remarkable growth. As a result, we are encountering a tough competition in this area and this competition is getting tougher. Active enterprises in this area should not ignore marketing and consumer behavior studies if they intend to stay competitive in this market. Furthermore, we know well that the product of airlines is often offered as a service whose main feature is its intangibility because service is an intangible activity or benefit offered by one side to the other without invoking a sense of ownership (Kotler, 2002). Offering service requires special type of marketing because in addition to four Ps in the marketing mix, four other factors; that is, "process", "individuals", "physical evidences", and "promotion and education" are added to services marketing mix (Lovelock \& Wright, 1999). Thus, airlines require to study and to consider strategies concerning services marketing. However, the problem detected by the researcher in Iranian airlines is that they, 
for different reasons, don not pay sufficient attention to issues associated with marketing in general and issues associated with brand and its constructs like brand personality. Given this, this research investigates airlines' brand personalities and compares brand personality in state-owned airlines and private ones.

\section{Literature Review}

Since consumers consider brands as humans and attribute human features to them, it is possible to define brand personality dimensions by applying human personality dimensions to the field of brands (Gopal, 2006). Aaker (1997) defined a new five-dimension model for brands, which is known as brand personality scale (BPS) based on five-salient-dimension model of human personality. This study was considered as one of the earliest attempts for creating a model for measuring personality in brand marketing field. In the past, researchers used scales directly extracted from personality psychology and therefore the validity of their marketing studies was questioned. However, Aaker overcame this problem by suggesting a theoretical framework of brand personality based on personality five salient dimensions. Every aspect of this model contains some relevant characteristics. In sincerity dimension, for instance, features like down-to-earth and family-oriented are used. In addition, ruggedness dimension contains features like masculine and western (Guthrie, 2008). Aaker (1997) in her research in the U.S. asked 631 individuals to express their ideas about 40 brands choosing from 114 personality characteristics. With factor analysis of major components, she came up with her select five dimensions. The validity and reliability of her model were proved in statistical tests and eventually she achieved her five major dimensions of sincerity, excitement, competence, sophistication, and ruggedness. This model is applicable to all cultures and product categories.

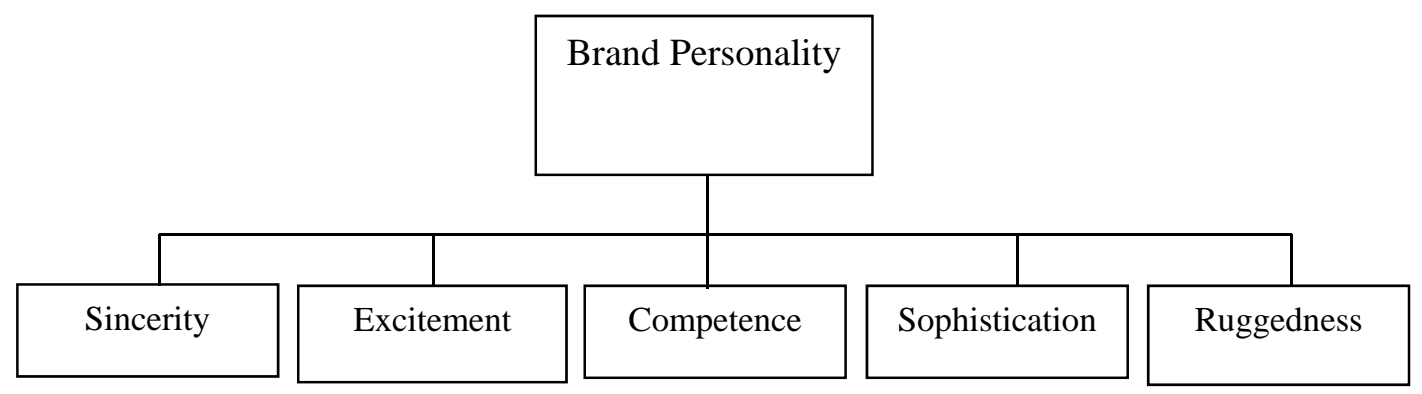

Fig. 1. The proposed model, Source: (Aaker, 2001)

Since this model is applicable to varıous cultures and product categories (Aaker, 1997), a lot of researchers have used this framework to investigate brand personality in different contexts. It has been used and referred to in more than one thousand studies (Kim et al., 2011). This shows high applicability of this brand personality construct. Table 2 shows some studies carried out in brand personality field, which indicates the acceptability and validity of Aaker brand personality model among researchers.

\section{Table 1}

The results of some studies carried out in brand personality field

\begin{tabular}{lllll}
\hline Author & Used Scale & Number of Dimensions & Setting & Culture \\
\hline Aaker (1997) & Own & 5 Dimension & Commercial Brands & United States \\
Austin, et al. (2003) & Aaker (1997) & 5 Dimension & Restaurants & United States \\
Davies, et al. (2001) & Aaker (1997) & 5 Dimension & Corporate Brands & United States \\
Venable, et al. (2005) & Aaker (1997) & 4 Dimension & Nonprofit Organizations & Russia \\
Supphellen, et al. (2003) & Aaker (1997) & 5 Dimension & Commercial Brands & United Kingdom \\
Rojas-Mendez, et al. (2004) & Aaker (1997) & 4 Dimension & Automobile Brands & Chile \\
Matzler, et al. (2006) & Aaker (1997) & 2 Dimension & Commercial Brands & Austria \\
Fennis, et al. (2007) & Aaker (1997) & 5 Dimension & Commercial Brands & Netherlands \\
Bosnjak, et al. (2007) & Aaker (1997) & 4 Dimension & Commercial Brands & Germany \\
Ranjbar, (2010) & Aaker (1997) & 5 Dimension & Automobile Brands & Iran \\
Sheena, (2012) & Aaker (1997) & 5 Dimension & FMCG Brands & India \\
\hline
\end{tabular}


In Iran, some relevant studies have been conducted too. Table 2 briefly discusses these studies.

Table 2

Some studies carried out in brand personality field in Iran

\begin{tabular}{lll}
\hline Researcher & Title & Results \\
\hline Dastjerdi, et al. (2009) & $\begin{array}{l}\text { Evaluating the position of Toshiba } \\
\text { brand personality in comparison } \\
\text { with four similar global brands in } \\
\begin{array}{l}\text { Iran's market using Aaker's five- } \\
\text { dimension model }\end{array}\end{array}$ & $\begin{array}{l}\text { In this study, researchers designed five hypotheses based on the } \\
\text { Sony in all dimensions. Samsung, Canon and Sharp placed in the } \\
\text { next positions. }\end{array}$ \\
Motameni, et al. (2011) & $\begin{array}{l}\text { The effect of brand personality on } \\
\text { costumers' loyalty }\end{array}$ & $\begin{array}{l}\text { In this study, four dimensions of brand personality including } \\
\text { Competence, Sincerity, Excitement and Upper-class was marked for }\end{array}$ \\
& $\begin{array}{l}\text { Irancell Company. The effect of brand personality on costumers' } \\
\text { perceived value and their satisfaction, effect of costumers' } \\
\text { satisfaction on their trust and loyalty and effect of costumers' } \\
\text { perceived value on their satisfaction and loyalty was proved as well. }\end{array}$ \\
\hline
\end{tabular}

\section{Research Methodology}

Given its purpose, this research is an application-oriented one and given its method, it is a descriptive study in the form of a survey. The research contains two kinds of variables: quantitative variable, which is the dependent variable compared in two research populations. In this study, it is brand personality. The other variable is classified variable, which is the independent one and differentiates two populations from each other. In this study, it is state-owned and private airlines (Mahan and Iran Air airlines). Aaker brand personality model with its 5 dimensions and 42 characteristics is used to investigate brand personality variable. Research hypotheses have been defined based on the model's five major dimensions and classified variable.

Main Hypothesis: Brand personalities of state-owned and private airlines are different in terms of technical directors of travel agencies.

Secondary Hypothesis 1: Brand personalities of state-owned and private airlines are different in the case of sincerity from the perspective of technical directors of travel agencies.

Secondary Hypothesis 2: Brand personalities of state-owned and private airlines are different in terms of excitement from the perspective of technical directors of travel agencies.

Secondary Hypothesis 3: Brand personalities of state-owned and private airlines are different in the case of competence from the perspective of technical directors of travel agencies.

Secondary Hypothesis 4: Brand personalities of state-owned and private airlines are different in the case of sophistication from the perspective of technical directors of travel agencies.

Secondary Hypothesis 5: Brand personalities of state-owned and private airlines are different in the case of ruggedness from the perspective of technical directors of travel agencies.

To evaluate indexes of research theoretical model, Aaker's five-dimension standard questionnaire was used. In this regard, first of all, relevant models were detected by studying books and articles and eventually, given the validity of this model in previous studies, the proper model for the research variable was selected and used. Time span of this research includes first of Feb. 2013 to the end of April 2013. Simple random sampling method was used for this study. Since research population includes 800 technical directors of travel agencies with license A in Tehran, Cochran's sample size formula with $95 \%$ certainty coefficient has been used for determining number of samples. 
$n=\frac{N \times z_{\alpha / 2}^{2} \times p \times q}{\varepsilon^{2} \times(N-1)+z_{\alpha / 2}^{2} \times p \times q}$,

where $N$ is the population size, $p=1-q$ represents the yes/no categories, $z_{\alpha / 2}$ is CDF of normal distribution and finally $\varepsilon$ is the error term. Since we have $p=0.5, z_{\alpha / 2}=1.96$ and $N=800$, the number of sample size is calculated as $n=233$. Since it was possible that a number of questionnaires were not filled out and returned, or they were not done fully, 280 questionnaires were distributed among research population. 243 questionnaires out of those which were distributed were returned among, which 8 questionnaires were not possible to use for they were carefully responded. Therefore, 235 questionnaires were considered as valid. Data were gathered by distributing questionnaires. The questionnaire was arranged in two sets of "questions related to demographic characteristics" and "questions related to research variables". There are five questions associated with demographic characteristics described selected statistical samples. Questions associated with research variables include brand personality variable, which contains five dimensions of sincerity, excitement, competence, sophistication, and ruggedness. Since these dimensions include 42 sub-characteristics in the model, 42 questions were asked. Measuring variables was accomplished by a five-option scale ranging from strongly agree, to strongly disagree.

Experts' opinions were used to make sure the content validity. Construct validity was measured using confirmatory factor analysis with the help of LISREL software for every measured construct. Analyzing internal structure of questionnaire and realizing the components of every construct or latent variable has been accomplished by using confirmatory factor analysis (Jöreskog \& Sörbom, 1993). Since t student statistical figure was confirmed for questions associated with sincerity, excitement, competence, sophistication, and ruggedness, all questions were used to measure these dimensions. Reliability was measured using Cronbach alpha coefficient. The measured alpha in the questionnaire was $81 \%$ for competence, $86 \%$ for sincerity, $81 \%$ for excitement, $80 \%$ for sophistication, $83 \%$ for ruggedness, and $93 \%$ for the research.

Given a large number of research samples, the normality of data was accepted. However, Kolmogorov-Smirnov test was used to test hypotheses and make sure of the normality of data. To measure reliability Cronbach alpha was used and construct validity was measured using confirmatory factor analysis with the help of LISREL software to determine whether questionnaire measures dimensions of brand personality or not. Finally, to measure research hypotheses with SPSS software compare means test was used. Fig. 2 shows the results of descriptive statistics of research.

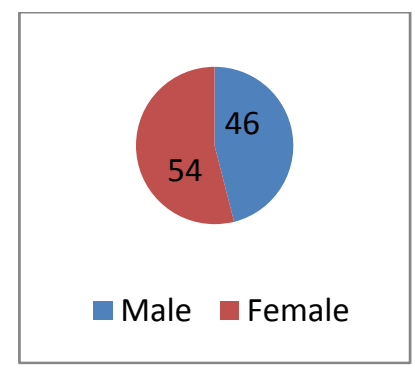

Gender

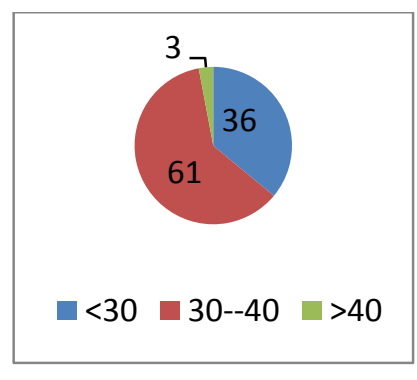

Age

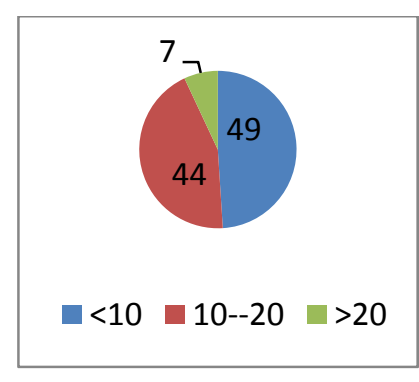

Job experience

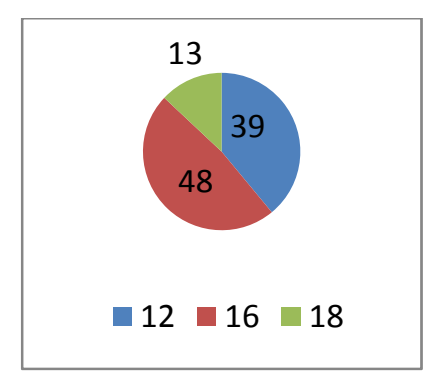

Year of education

Fig. 2. Personal characteristics of the participants

\section{Testing hypotheses}

To measure research hypotheses, the study uses t test with two independent samples, which is normally used to measure confidence interval or the hypothesis concerning the difference between means of two populations. Before the difference between means of two populations is studied, it is 
necessary to investigate the equality or lack of equality of two populations' variances. Thus, Levene test is used. If the level of significance of the test is more than $0.05, \mathrm{H}_{0}$ hypothesis is accepted and one can claim the variances of two populations are equal. In addition, in compare means test when variances are equal or not equal, if the level of significance is below 0.05 , hypotheses are accepted in $95 \%$ level of certainty.

Table 3

Independent Samples T Test for the main hypothesis: Brand Personality

\begin{tabular}{|c|c|c|c|c|c|c|c|c|}
\hline \multirow{2}{*}{ Variable } & \multirow{2}{*}{ Airline } & \multicolumn{3}{|c|}{ Levene Test } & & \multirow{2}{*}{$\mathrm{T}$} & \multicolumn{2}{|c|}{ Confidence Interval (95\%) } \\
\hline & & Sig. & Error & Mean & Std. Deviation & & Lower & Upper \\
\hline \multirow{2}{*}{ Brand Personality } & Private & & \multirow{2}{*}{0.05} & 3.70 & 0.40 & \multirow{2}{*}{14.03} & \multirow{2}{*}{0.52} & \multirow{2}{*}{0.69} \\
\hline & State owned & & & 3.09 & 0.52 & & & \\
\hline
\end{tabular}

Given the significance level of Levene test, the hypothesis concerning variances' inequality is accepted and the second row of compare means test is used. As Table 3 shows, given the significance level, $\mathrm{H}_{1}$ hypothesis is accepted in the $99 \%$ level of certainty. In other words, the mean of brand personality variable is significantly different between private sector (Mahan Airlines) and stateowned sector (Iran Air). As the last column of the table shows, the mean difference in certainty level of $99 \%$ is positive in two sides of high and low limits. This indicates the mean of brand personality variable in private sector is more than the one in state-owned sector. Thus, the main hypothesis is accepted.

We now present details of our findings on testing all hypotheses of the paper and Table 4 shows the results of our findings.

Table 4

The results of testing sub-hypotheses

\begin{tabular}{|c|c|c|c|c|c|c|c|c|c|}
\hline \multirow{2}{*}{ Variable } & \multirow{2}{*}{ Airline } & \multicolumn{2}{|c|}{ Levene Test } & \multirow[b]{2}{*}{ Mean } & \multirow[b]{2}{*}{ Std. Deviation } & \multirow{2}{*}{$\mathrm{t}$} & \multirow{2}{*}{ Sig. } & \multicolumn{2}{|c|}{ Confidence Interval (95\%) } \\
\hline & & Sig. & Error & & & & & Upper & Lower \\
\hline \multirow[t]{2}{*}{ Competence } & Private & 0.333 & \multirow{2}{*}{0.05} & 3.63 & 0.66 & \multirow{2}{*}{10.41} & \multirow{2}{*}{0.000} & \multirow{2}{*}{0.79} & \multirow{2}{*}{0.54} \\
\hline & State-owned & & & 2.96 & 0.72 & & & & \\
\hline \multirow[t]{2}{*}{ Sincerity } & Private & 0.000 & \multirow{2}{*}{0.05} & 3.88 & 0.46 & \multirow[t]{2}{*}{13.49} & \multirow[t]{2}{*}{0.000} & \multirow[t]{2}{*}{0.78} & \multirow[t]{2}{*}{0.58} \\
\hline & State-owned & & & 3.20 & 0.61 & & & & \\
\hline \multirow[t]{2}{*}{ Excitement } & Private & 0.099 & \multirow{2}{*}{0.05} & 3.64 & 0.51 & \multirow{2}{*}{10.40} & \multirow{2}{*}{0.000} & \multirow{2}{*}{0.62} & \multirow{2}{*}{0.42} \\
\hline & State-owned & & & 3.11 & 0.57 & & & & \\
\hline \multirow[t]{2}{*}{ Sophistication } & Private & 0.298 & \multirow{2}{*}{0.05} & 3.57 & 0.59 & \multirow{2}{*}{8.85} & \multirow{2}{*}{0.000} & \multirow{2}{*}{0.60} & \multirow{2}{*}{0.38} \\
\hline & State-owned & & & 3.07 & 0.62 & & & & \\
\hline \multirow[t]{2}{*}{ Ruggedness } & Private & 0.000 & \multirow{2}{*}{0.05} & 3.79 & 0.63 & \multirow{2}{*}{9.23} & \multirow{2}{*}{0.000} & \multirow{2}{*}{0.79} & \multirow{2}{*}{0.51} \\
\hline & State-owned & & & 3.13 & 0.87 & & & & \\
\hline
\end{tabular}

As Table 4 shows, given the significance level of aforementioned tests, two populations are different in brand personality dimension in $99 \%$ of certainty. In addition, given the high and low limits in Table 4, it can be said that private sector, that is Mahan Airlines, is in a higher level in all dimensions of model as compared to state-owned sector, here Iran Air. Therefore, all secondary hypotheses of research are accepted.

\section{Discussion and Conclusion}

As the results of analyses indicate, Mahan which represents private sector is superior to Iran Air as the representative of state-owned sector in all five dimensions of Aaker model (1997). Since Mahan Airline is a private company, it is clear that profitability and revenue in short-run and long-run are important for the managers of this company and are considered as their priorities. Therefore, it is clear that this company pays more attention to market and marketing issues while Iran Air as a stateowned company has no worry about future, revenue is not a big deal for its managers, and therefore this industry is not a competitive one for them. Due to this stance, this company does not make use of 
its capacities and only wants to survive in this industry. This perspective can be summarized in one sentence. As one technical director maintains, Iran Air is blind to market.

What is the manifestation of this different attitude to market and marketing in the performance of these two companies? How the quality of their services as well as imagination of brand personality taken shape in technical directors of agencies? To answer these questions, the performance of these two companies has been investigated.

As mentioned earlier, the population of this study includes technical directors of agencies and what they have answered to research questions is the result of their contacts and experiences with these two companies or the reflection of their customers' experiences as the passengers of these two airlines. The first contact point of these individuals with airlines is through reservation system. Iran Air's system is called Gabriel, which is considered as an old system. Mahan's system, however, is exclusive and can be considered as its unique characteristics. Technical directors maintain that this rather new and modern system is more accessible, more secure, easier to use, more clever and certain and less vulnerable to errors. Users of Mahan reservation system state that it is accessible in every time and place through internet with a password and username. In addition, the design of this website allows users to have access to more information such as purchase possibility and ticket price faster and easier. Different features in Mahan reservation system as compared with those of Iran Air such as being modern, clever, secure, unique, safe, etc. are considered in sincerity, excitement, competence, sophistication, and ruggedness and therefore from the very first contacts, a different and better image of Mahan brand personality takes shape.

Among other differentiating features of Mahan as compared with Iran Air from the perspective of technical directors, one can refer to its attention to directors and employees of travel companies. Things like travel offerings and free tickets based on sales volume of these companies and holding especial seminars for technical directors can be mentioned. These rewarding and promotional initiatives create loyalty and help Mahan reach better understanding of the market. Before inaugurating any direction, Mahan negotiates and consults technical directors upon the success of the new direction and passengers' attitude in different seminars. Through these seminars, Mahan updates and introduces its product. In general, Mahan updates once in every two or three months while Iran Air updates once in every two or three years. This indicates having characteristics such as cooperation atmosphere, intimacy and kindness, being update, industriousness, and being technical and professional. In sincerity, excitement, and sophistication these characteristics are referred to.

Customer clubs of these tow companies should also be mentioned. Though Iran Air is superior to other Iranian Airlines in this regard, it has not been successful in its competition with Mahan. According to technical directors, compared to Iran Air's Skygift, Mahan and Miles has a better performance both in the number of members and in advantages and services. More members of this club indicates a higher level of trust and loyalty among customers for this company. Another benefit of having more members is more effective word of mouth advertising.

Mahan's air craft is also newer, more modern and more advanced than that of Iran Air. Mahan realized, much sooner than other Iranian airlines, that passengers didn't trust Russian made airplanes and thus replaced these airplanes with Airbus and Boeing airplanes. Before prohibiting the flight of Russian made airplanes, Iran Air had the largest number of these airplanes. Even after it decided to renew its air craft, Iran Air made a mistake by giving its old and inefficient airplanes to Iran Air Tour. This contaminated the brand personality of Iran Air Tour and, given the similarity between these two brands, Iran Air Tour weakness was applied to Iran Air too. Therefore, it is no surprise that technical directors consider Mahan superior to Iran Air based on characteristics such as power and authority, strength, being high class, trustworthiness, and being modern. 
Perhaps the first contact points of passengers with airlines occur in the airport. It is likely that passengers before doing anything check the exact departure time. They expect this time matches the one written on their tickets. If these two times are not matched and flight is delayed, certain situations may be at work. Are passengers informed of this delay in advance? Is there any plan designed for wandering passengers in the airport? In addition, most important of all, is this delay due to climatic conditions or technical issues? Technical directors maintain that Mahan has a much better performance in delayed flights. Given the number of delayed flights, Mahan has a better status that Iran Air. Delays resulting from climatic conditions are acceptable for passengers and don't contaminate company brand but technical delays have negative effects on characteristics such as safeness, security, being modern, strength, power and authority, honesty, and resilience in passengers' minds.

In general, it can be said that technical directors of agencies state that in most of its contact points with passengers like receiving flight card, giving and taking luggage, flight attendants and crew coverage and behavior, pilot's relation with passengers, flight quality, quality of services during flight, etc., Mahan is more attractive, more modern, happier, more trustworthy, stronger, more intimate, and more professional than Iran Air which eventually leads to its better brand personality in all dimensions.

\section{Research Practical Suggestions}

Given the model dimensions, the following suggestions can be used by airlines especially Mahan and Iran Air:

1. As it is shown, Iran Air is not in good position in all dimensions of brand personality. The research maintains that the reason is how managers of this company approach this issue. This research recommends Iran Air and similar state-owned companies to change their attitude from survival to revenue-making, competition and marketing. State-owned companies often have access to unlimited financial resources, special privileges and benefits, and exclusive markets and therefore they have little worry about future and this leads to having dissatisfied consumers. However, with the gradual growth of private companies, state-owned ones lose their benefits and customers. Competition will even threaten their survival. Thus, the research recommends these companies to design strategies and appropriate perspectives in all areas of marketing, embrace competition and marketing, and create a context of growth and development.

2. Research observations as well as technical directors' opinions indicate that Mahan has been successful in its contacts with travel agencies and technical directors and has directed most of its marketing focus on this part and therefore employees of travel agencies recommend passengers to travel with Mahan flights. Mahan Airline, however, has paid little attention to direct marketing with end customers and consumers. Tools used for creating this relation should be considered so that they can enhance brand personality of their company. Using up-to-date and modern technologies in advertising and promotional activities can, for instance, fit the personality of this brand. Having strategies for social networks and virtual space - a neglected area so far - is also helpful.

3. Advertising and designing appropriate advertising campaigns in suitable and efficient media is another suggestion to consider. As mentioned earlier, travel companies in general and Mahan and Iran Air in particular think of no special plans for having direct relations with end consumers and advertising is a form of this relation. Especial care and attention is necessary when designing advertisements because advertising is one of the most efficient tools for creating brand personality. TV commercials, for instance, cannot be suitable for big and well-known companies such as Mahan and Iran Air because these companies don't need to introduce themselves and attract customers. Such companies need to choose a way or media for advertising, which shows their differentiation and delivers a sense of excellence. One way to create such sense is using celebrities such as artists and 
athletes in advertising. By doing so, companies can apply personality traits of that particular person to their own product or service.

Another point to consider when making and improving brand personality through advertising is using metaphors in ads. Since brand personality and its dimension are abstract concepts, metaphors can make these concepts more concrete and lasting (Ang \& Lim, 2006). In this case, selected metaphors should fit brand personality and delivers, for instance, tranquility, security, safety, intimacy, strength, etc.

4. In competing with local companies, Mahan has been successful and has provided the satisfaction of its customers. In competing with foreign companies, however, these are not considered as competitive advantage. Here, inspiring a feeling a pride and excellence should be their aim. What happens to foreign flights of Mahan in particular is that passengers are cared about and their needs are responded properly from the beginning till the end of the journey. Once passengers get off board and enter the destination airport, however, things like different behaviors toward passengers of Iranian companies, more intensive security strategies and different attitudes can, in the best case, make passengers enjoy only their flight but senses of pride and excellence are never expected to arise in Iranian passengers. The research suggests establishing suitable relationships and more contacts with embassies, airports, and authorities in host countries. Technical directors maintain that Mahan has been successful to solve this problem in some destinations such as Bangkok and Delhi.

\section{Suggestions for Future Studies}

- Reusing this model in other areas of tourism industry such as restaurants, museums, parks, and other tourism attractions.

- Investigating and exploring factors effecting different dimensions of brand personality and analyzing consequences and results of these dimensions

- Investigating the effect of different marketing initiatives on brand personality dimensions and prioritizing effective tools for creating brand personality

- Investigating the relation between brand personality construct and other theoretical concepts in brand and marketing areas like brand awareness, brand equity, brand preference, repetitive buying behavior, etc.

- Designing and using qualitative methods such as focus group, deep interviews, ZMET, neuromarketing, and other advanced qualitative methods for studying brand personality

\section{Research Obstacles and Limitations}

- The difficulty of arranging a time with technical directors to answer questionnaires and their reluctance for cooperation

- Bias of respondents toward one of the brands under study

- Halo effect (when judgment about personality features is under the influence of a general understanding of a brand)

- Limiting population to technical directors. Therefore, the results of this research don't necessarily reflect brand personality positions of these two companies with end consumers though technical directors views somehow reflect views of customers.

- Investigating brand personalities of these companies comparatively. It should be added that if brand personalities of any of these companies were studies solely or in relation with other local or foreign companies, their position would change. 


\section{References}

Aaker, J. L. (1997). Dimensions of brand personality. Journal of Marketing Research, 34 (3), 347.

Ang, S. H. \& Lim, E. A. (2006). The Influence of Metaphors and Product Type on Brand Personality Perceptions and Attitudes. Journal of Advertising, 35(2), 39-53.

Asperin, A. E. (2007). Exploring Brand Personality Congruence. Kansas: UMI.

Austin, J. R., Siguaw, J. A., \& Mattila, A. S. (2003). A re-examination of the generalizability of the Aaker brand personality measurement framework. Journal of Strategic Marketing,11 (2), 77-92.

Biel, A. (1993). Converting Image into Equity. In D. A. Aaker, \& A. Biel, Brand Equity and Advertising: Advertising's Role in Building Strong Brands (Advertising and Consumer Psychology) (pp. 67-83). New Jersy: Lawrence Erlbaum Associates.

Bosnjak, V., Bochmann, M., \& Hufschmidt, T. (2007). Dimensions of brand personality attributions: A person-centric approach in the German cultural context. Social Behavior and Personality, 35 (3), 303-316.

Davies, G., Chun, R., da Silva, R. V., \& Roper, S. (2001). The personification metaphor as a measurement approach for corporate reputation. Corporate Reputation Review, 4 (1), 113-127.

Dohee Kim, V. M. (2011). The effects of customers' perceptions of brand personality in casual theme restaurants. International Journal of Hospitality Management, 30 (2), 448-458.

Fennis, B. M., \& Pruyn, A. T. (2007). You are what you wear: Brand personality influences on consumer impression formation. Journal of Business Research, 60 (6), 634-639.

Fournier, S. (1994). A consumer-brand relationship framework for strategic brand management. Doctoral Dissertation , University of Florida.

Gopal, R. (2006). Brand excellence: measuring the impact of advertising and brand personality on buying decisions. Emerald Group Publishing Limited, 10 (3), 56-65.

Guthrie, M., Kim, H.-S., \& Jung, J. (2008). The effects of facial image and cosmetic usage on perception of brand personality. Journal of Fashion Marketing and Management Decision, 12 (2), 164-181.

Jöreskog, K. G., \& Sörbom, D. (1993). LISREL 8: Structural equation modeling with the SIMPLIS command language. Scientific Software International.

Kotler, P. (2002). Marketing Management, Millenium Edition. Boston: Pearson Custom Publishing.

Lovelock, C. H., \& Wright, L. (1999). Principles of Service Marketing and Management. New Jersey: Prentice Hall.

Matzler, K., Bidmon, S., \& Krauter, S. G. (2006). Individual determinants of brand affect: the role of the personality traits of extraversion and openness to experience. Journal of Product \& Brand Management, 15 (7), 427-434.

Motameni, A., Moradi, H., \& Hemmati, A. (2011). The effect of brand personality on costumers' loyalty. Journal of Business Management Vision, 4, 89-105.

Muhammadian, M., Farahmand, S., \& Yousefi Dastjerdi, M. (2009). Evaluating the position of Toshiba brand personality in comparison with four similar global brands in Iran's market using Aaker’s five-dimension model. Journal of Marketing Management, 2(4), 129-144.

Naresh, G. (2012). Do brand personalities make a difference to consumers?.Procedia-Social and Behavioral Sciences, 37, 31-37.

Ranjbar, S. (2010). Application of brand personality scale in automobile industry- the study of Samand's brand personality dimensions. Lulea university of Technology , Master Thesis.

Rojas-Mendez, J. I., Erenchun-Podlech, I., \& Silva-Olave, E. (2004). The Ford brand personality in Chile. Corporate Reputation Review, 7 (3), 232-251.

Sirgy, J. (1982). Self-concept in consumer behavior. Journal of Consumer Research, 9 (3), 287-300.

Supphellen, M., \& Gronhaug, K. (2003). Building foreign brand personalities in Russia: the moderating effect of ethnocentrism. International Journal of Advertising, 22 (2), 203-226.

Venable, B. T., Rose, G. M., Bush, V. D., \& Gilbert, F. W. (2005). The role of brand personality in charitable giving: An assessment and validation. Journal of the Academy of Marketing Science, 33 (3), 295-312. 